\title{
Daily activity, feeding and rations in gobies and brown shrimp in the northern Wadden Sea
}

\author{
A. G. C. del Norte-Campos, A. Temming \\ Institut für Hydrobiologie und Fischereiwissenschaft, Universität Hamburg, Olbersweg 24, D-22767 Hamburg, Germany
}

\begin{abstract}
A $24 \mathrm{~h}$ trawl fishery was conducted near the island of Sylt, northern Wadden Sea, Germany, to investigate and compare daily patterns of activity and feeding among the gobies Pomatoschistus microps Krøyer and $P$. minutus Pallas and the brown shrimp Crangon crangon L. Relative occurrence of the 3 species was generally consistent, with C. crangon dominating at about $93 \%$, except at midnight, when $P$. minutus and $P$. microps occurred at $68 \%$ and $12 \%$, respectively. Peak abundances of $C$. crangon and $P$. minutus occurred at dawn and of $P$. microps at sunrise, coinciding with rising tide. Size distributions for the 3 species were constant on a diurnal basis. Intensity of feeding among the gobies was highest during daylight hours, at dusk and sunrise, whereas a feeding peak in shrimp occurred at dawn, with very little feeding at noon. Feeding peaks of the 3 species therefore roughly coincided with peak activity periods. Smaller specimens of the 3 species fed mostly on meiofauna, switching gradually to macrofauna with increase in size. Over a 24 h period, C. crangon cannibalism was low, but predation of $P$. minutus on $C$. crangon was prevalent, ranging from about $28 \%$ of total gut contents by ashfree dry weight (<55 mm gobies) to $77 \%$ ( $>55 \mathrm{~mm}$ gobies). On a population basis, however, this predation was only equivalent to $0.3 \%$ of the total available biomass of shrimp, although with highest proportions among the new recruits. Gastric evacuation rates and resulting daily rations are comparable with the range of values in the literature.
\end{abstract}

KEY WORDS: Activity Feeding Daily rations Gobies - Brown shrimp - Wadden Sea

\section{INTRODUCTION}

The gobies Pomatoschistus microps Kroyer and $P$. minutus Pallas and the brown shrimp Crangon crangon L are common inhabitants of shallow-water habitats on European coasts (Tiews 1970, Fonds 1973, Miller 1973). They co-occur in high abundances and exploit similar resources over a relatively short season. These species have been reported to prey upon each other, depending on the timing of arrival of new recruits (Kühl 1972). Gobies, moreover, are reported to be one of the major predators of brown shrimp (Kühl 1964, Tiews 1978, Redant 1980) and responsible for the destruction of summer shrimp broods (Kuipers \& Dapper 1984). Shrimp cannibalism is also quite commonly reported in the literature (Rolle 1982, Evans 1983), but its importance still remains unclear.

The dynamics of seasonal resource utilization by these species have been reported by other authors, such as Evans \& Tallmark (1979, 1984, 1985), Pihl \& Rosenberg (1982), Thorman (1982) and Thorman \& Wiederholm $(1983,1984,1986)$ in Sweden. Daily patterns of resource utilization and how these are affected by abiotic factors were studied by Gibson \& Hesthagen (1981) and Antholz et al. (1991), among others. In these latter studies, the species were considered separately.

To determine the nature of interactions among these 3 species and the extent to which they influence each other, we described and compared their daily patterns of activity and feeding in the the northern Wadden Sea region. Patterns of relative co-occurrence, densities, stomach fullness and prey utilization were analyzed for a $24 \mathrm{~h}$ cycle. Overall niche overlaps between species and by length classes were compared, and the impact of predation in terms of available biomass was assessed. Daily rations were calculated and compared with values in the literature. 


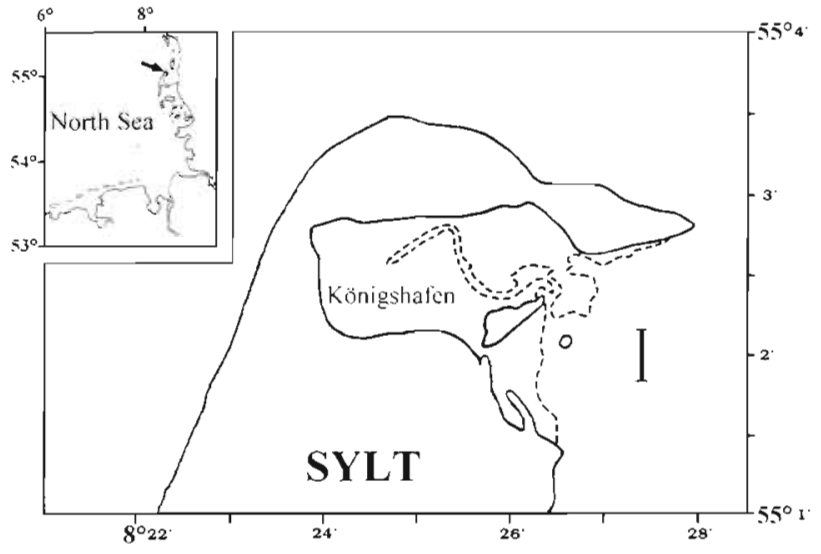

Fig. 1. Location of the sampling site in Königshafen, Sylt island (Germany), northern Wadden Sea. Thick bar indicates general location of tows

\section{MATERIALS AND METHODS}

The study was conducted off Königshafen, on the northeast coast of Sylt island, northern Wadden Sea $\left(55^{\circ}\right.$ $01.95^{\prime} \mathrm{N}, 08^{\circ} 27.38^{\prime} \mathrm{E}$ ) (Fig. 1) in July 1992. The subtidal area is predominantly sandy and has a mean tidal range of $1.8 \mathrm{~m}$. Samples were taken with a small vessel, using a $2 \mathrm{~m}$ beam trawl with a $5 \mathrm{~mm}$ mesh at the cod end. Hauls were done at depths ranging from 4 to $7 \mathrm{~m}$ during high tide and 2 to $5 \mathrm{~m}$ during low tide. Haul intervals were roughly $1.5 \mathrm{~h}$, starting at $13: 58 \mathrm{~h}$ and continuing until 14:47 h the next day, or a total of 17 hauls. Hauls generally lasted around $10 \mathrm{~min}$. Average haul length and area were about $522 \mathrm{~m}$ and $1044 \mathrm{~m}^{2}$, respectively. Hauling velocity was on average 2 to 3 knots.

Catches were taken on board and sorted, and total catch per species was recorded. Species densities by haul (ind. $\mathrm{m}^{-2}$ ) are plotted to depict activity patterns over a $24 \mathrm{~h}$ period. Random samples of gobies and shrimp were taken from each haul and preserved in $70 \%$ alcohol. In the laboratory, the specimens were measured to the nearest $\mathrm{mm}$ and then grouped into $5 \mathrm{~mm}$ length classes. Total lengths of shrimp were taken by measuring from the tip of the scaphocerite to the tip of the telson. Individual cohorts of each species were separated using the Bhattacharya method incorporated in the ELEFAN package (Gayanilo et al. 1989).

From each sample, at least 3 to 4 individuals per length class were taken for stomach content analysis. Since the gobies do not have a distinct stomach, the whole alimentary canal between the esophagus and rectum was taken, whereas only the foregut of shrimps was removed. Stomach content wet weights $(g)$ were calculated from the difference of the weights of stomachs with contents and their corresponding stomach walls. Ash-free dry weights (AFDW) were assigned to meiofauna and plankton found in the guts using values in the literature (Faubel 1982, Pihl 1985). Remaining parts of larger prey (macrofauna) were measured under the stereomicroscope and then expressed as total length and corresponding AFDW using regressions and length-weight relationships taken from the literature (e.g. Sander 1987). Total gut contents by length class and for each sample was expressed in percentage frequencies by prey item based on weight.

Fullness index (FI, in \%) was computed for each individual following the equation of Hureau (1969):

$$
\mathrm{FI}=\frac{S}{W} \times 100
$$

where $S$ is wet weight $(\mathrm{g})$ of stomach contents and $W$ is body wet weight $(\mathrm{g})$ of fish or shrimp, without stomach contents. The means of the fullness indices were plotted against actual time of haul to depict the diel feeding pattern.

Food niche overlaps were calculated according to the equation:

$$
C_{x y}=\sum \min \left(P_{x i}, P_{y i}\right)
$$

given by Hurlbert (1978), where $P_{x l}$ is relative frequency (by weight) of prey item $i$ in the stomach of species $x_{i} P_{y i}$ is the corresponding frequency in species $y$. The value of $C_{x y}$ varies from 0 for no overlap to 1 for complete overlap. Classifications of prey items, on which food niche overlaps were based, were kept similar for all 3 predators. Food niche overlaps between species were compared by haul and also by length class to investigate the effect of predator size and weight.

To test the significance of changes in feeding intensity, 2 consecutive minima and 1 intermediate maximum of the fullness indices by species were compared using a Mann-Whitney test (Sokal \& Rohlf 1981).

Evacuation rates were estimated by fitting negative linear curves to the descending segments of the fullness indices which were plotted against actual time of hauls. Hauls 10 to 15 (3:58 to $11: 26 \mathrm{~h}$ ) were used for Crangon crangon, whereas for both gobies, hauls 6 to 8 (21:30 to 01:21 h) were used (see Fig. 4). Daily food rations were estimated using Bajkov's (1935) linear model:

$$
F=R \times 24 \mathrm{~h}
$$

where $F$ is the daily food ration in $g$ or \% body weight and $R$ the evacuation rate in $\mathrm{g} \mathrm{h}^{-1}$ or \% body weight $\mathrm{h}^{-1}$. To facilitate comparison of values in the literature, we also computed the daily rations using the exponential model, as follows:

$$
F=E S \times 24 \mathrm{~h}
$$

where $E$ is the exponential coefficient and $S$ the average stomach content in $\mathrm{g}$ or $\%$ body weight. 


\section{RESULTS}

\section{Predator activity and relative occurrence}

Overall percentage occurrence of Crangon crangon relative to the gobies was $93 \%$. Percentage occurrence of Pomatoschistus minutus was $6 \%$, while that of $P$. microps was $0.6 \%$, C. crangon showed consistent dominance in number over the gobies, except around midnight and noon (i.e. 00:21 and 13:01 h), when its occurrence decreased. At these times, percentage occurrences of $P$. minutus and $P$. microps were 68 and $3 \%$, respectively, for $00: 21 \mathrm{~h}$ and 12 and $2 \%$, respectively, for 13:01 h.

Over the $24 \mathrm{~h}$ period, the size distributions of the 3 species did not change much from one haul to the next. Three shrimp cohorts could be separated, with mean lengths of 24.7, 36.6 and $54.5 \mathrm{~mm}$, respectively (Fig. 2a). Pomatoschistus minutus had 3 cohorts with mean lengths of $31.3,43.8$ and $70.6 \mathrm{~mm}$ (Fig. 2b). Much fewer $P$. microps were caught during the 24 h period: there were 2 cohorts present, with mean lengths of 27.2 and $43.9 \mathrm{~mm}$ (Fig. 2c). Range of sizes caught was 11 to $69 \mathrm{~mm}$ for Crangon crangon, 21 to $84 \mathrm{~mm}$ for $P$. minutus and 17 to $45 \mathrm{~mm}$ for P. microps.

Despite the absence of replicate tows, the results show trends in the densities of the species over the $24 \mathrm{~h}$ period. The highest density peak for Crangon crangon and Pomatoschistus minutus occurred at dawn 103:58 h), coinciding with the period between low and high tide (Fig. 3a, b). During this time, the density of $C$. crangon was 17 ind. $\mathrm{m}^{-2}$ and that of $P$. minutus was 0.4 ind. $\mathrm{m}^{-2}$. The peak density of $P$. microps $(=0.06$ ind. $\mathrm{m}^{-2}$ ) occurred some hours later (06:59 h), just after sunrise (Fig. 3c), and coincided with rising tide. Lowest shrimp densities occurred just after midnight $(0.01$ ind. $\mathrm{m}^{-2}$ ) and after noon ( 0.4 ind. $\mathrm{m}^{-2}$ ), both just before low tide. The pattern of occurrence of lowest densities of $P$. minutus was less pronounced, whereas that of $P$. microps was also similar to the pattern shown by $C$. crangon, with lowest densities around midnight and noon.

\section{Diel feeding intensity}

Differences between 2 consecutive minima and the intermediate maximum fullness indices were all significant (Table 1), indicating that significant increase ( $p<$ $0.05)$ and decrease $(p<0.01)$ in the level of feeding in the 3 species occurred.

A total of 553 Crangon crangon individuals representing all length classes available were examined for their gut contents. Fig. $4 \mathrm{a}$ shows the $24 \mathrm{~h}$ feeding pattern of C. crangon based on fullness indices. Increased feeding was observed in the afternoon, followed by a
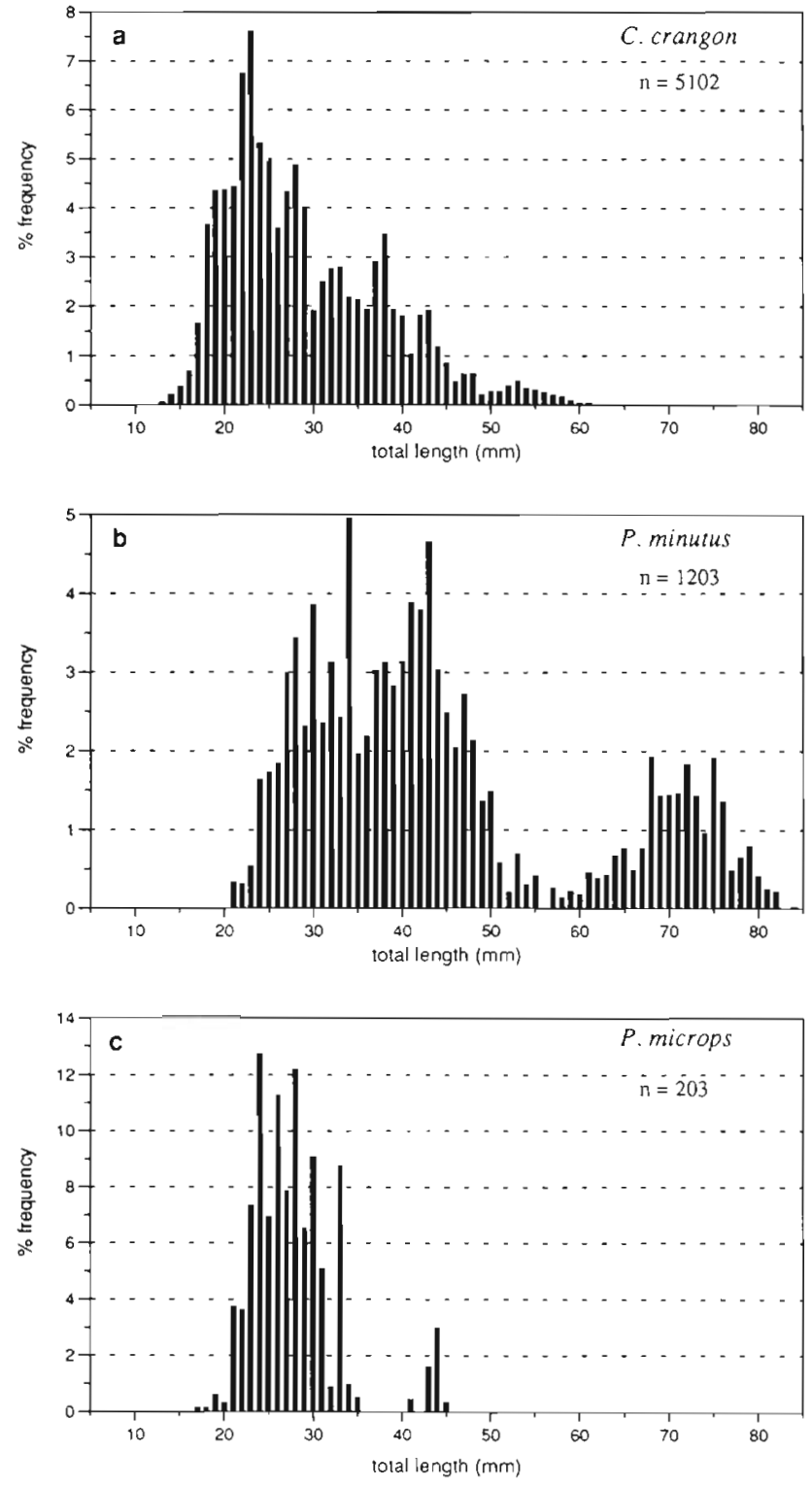

Fig. 2. Overall size distributions of (a) Crangon crangon, (b) Pomatoschistus minutus and (c) P. microps

Table 1. Crangon crangon, Pomatoschistus minutus and $P$. microps. Comparison of means of fullness indices $(2$ consecutive minima and the intermediate maximum)

\begin{tabular}{|lcc|}
\hline Species and haul & $\mathrm{n}$ & Mann-Whitney test \\
\hline P. microps & & \\
Haul 4 vs haul 5 & 12 & $U=18^{\circ}$ \\
Haul 5 vs haul 8 & 19 & $z=112 \cdots$ \\
P. minutus & & $z=2.82^{\cdots}$ \\
Haul 4 vs haul 6 & 51 & $z=4.42 \cdots$ \\
Haul 6 vs haul 8 & 42 & $z=5.21 \cdots$ \\
C. crangon & & \\
Haul 8 vs haul 10 & 47 & \\
Haul 10 vs haul 14 & 55 & \\
\hline
\end{tabular}



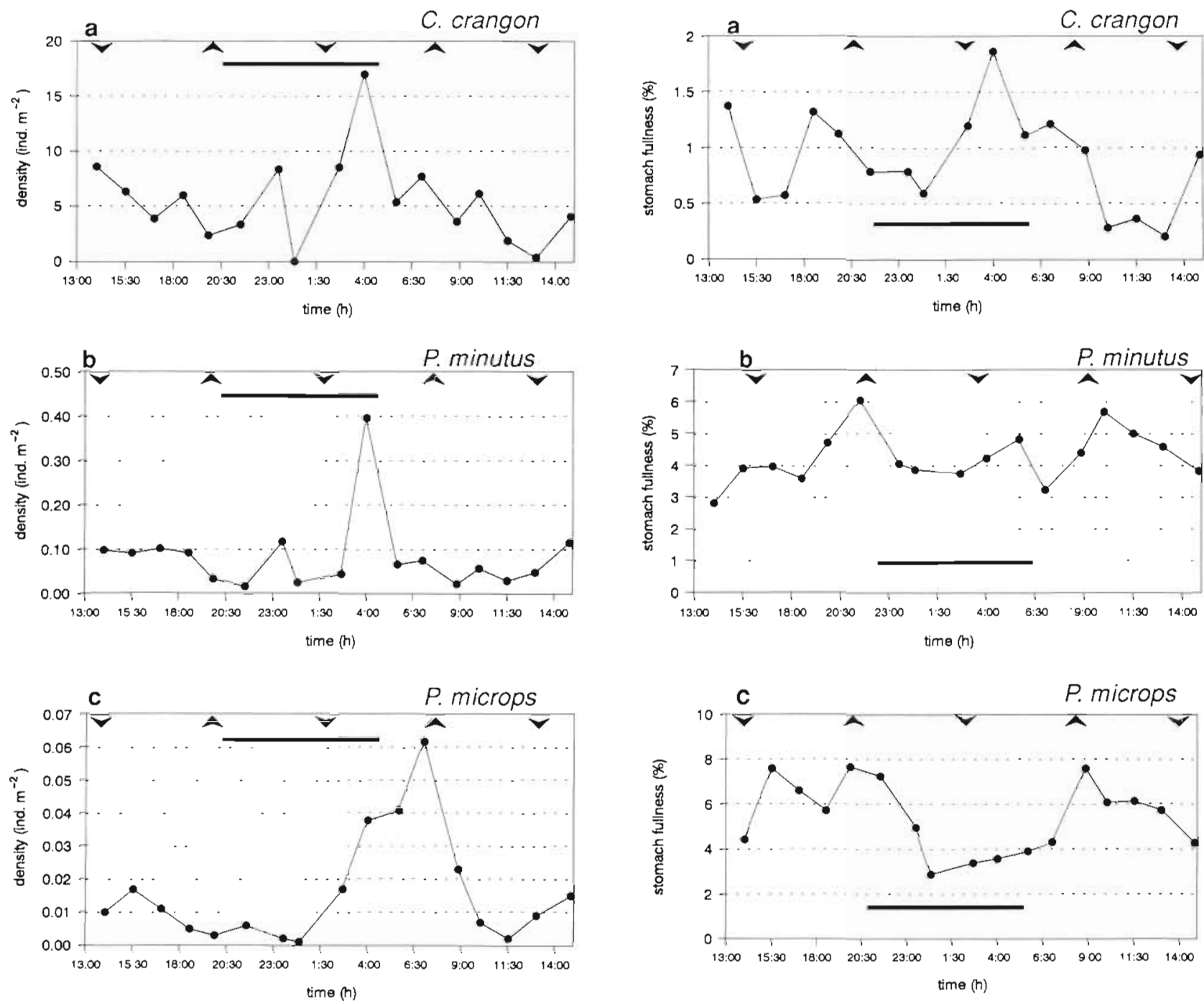

Fig. 3. Diel density patterns of (a) Crangon crangon, (b) Pomatoschistus minutus and (c) P. microps. Arrows: low $(\checkmark)$ and high( $\boldsymbol{A}$ ) tides; thick bar: nighttime

Fig. 4. Diel feeding patterns of (a) Crangon crangon ( $\mathrm{n}=553)$, (b) Pomatoschistus minutus $(\mathrm{n}=447$ ) and (c) P. microps ( $\mathrm{n}=$ 184). Other symbols as in Fig. 3

period of decreased feeding towards dusk. After midnight, feeding increased, attaining its peak at dawn, until just before sunrise, after which little feeding was observed until noon. The peaks of feeding observed coincided with the period between low and high tide, and paralleled closely the observed activity pattern.

Some 447 individuals of Pomatoschistus minutus were examined for gut contents. Stomach fullness increased with the rising tide and was highest during $(08: 54 \mathrm{~h})$ or shortly after $(21: 30 \mathrm{~h})$ slack high tide (Fig. 4b). The peak in fullness observed at 08:54 h was slightly delayed relative to the peak in density.

In comparison, less Pomatoschistus microps occurred in the samples, so that almost all individuals caught ( $\mathrm{n}$ $=184$ ) were examined for gut contents. Fig. $4 \mathrm{c}$ shows the diel feeding pattern of $P$. microps. Deviations from

an otherwise clear course of feeding were observed in some hauls where low catches occurred (e.g. 08:54 h). One may, however, roughly delineate 2 main feeding periods, one between afternoon $(15: 30 \mathrm{~h})$ and dusk (19:53 $\mathrm{h})$ and the other after sunrise. In general, feeding was highest at slack high tide and decreased with the outgoing tide.

\section{Diet composition}

Stomach contents of the 3 species expressed as \% AFDW were summarized for the entire $24 \mathrm{~h}$ period by grouping together related prey items and presented according to the size of the predator. Fig. $5 a$ shows the diet composition of Crangon crangon by length class. 


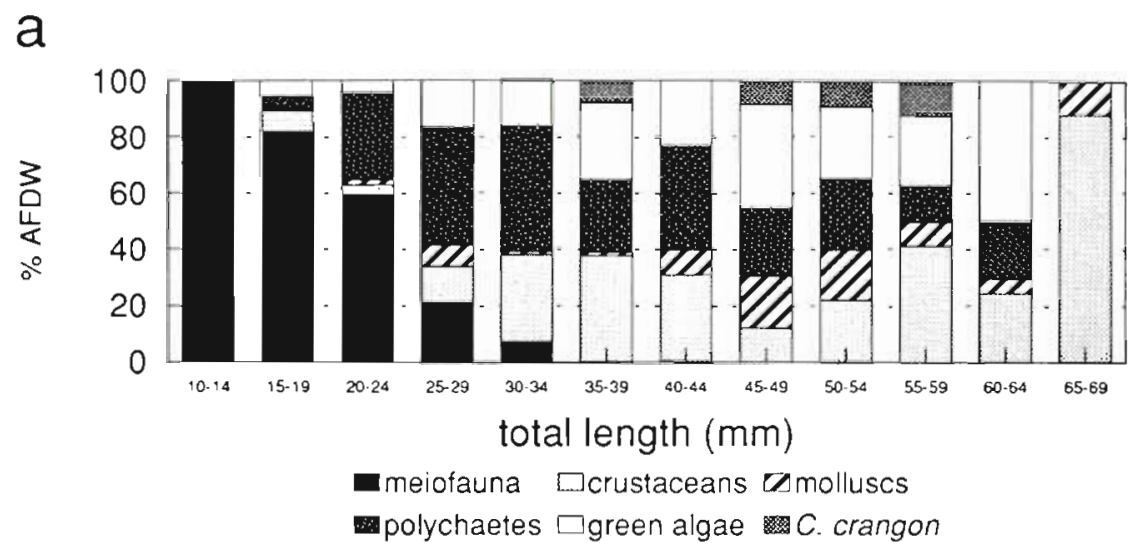

b
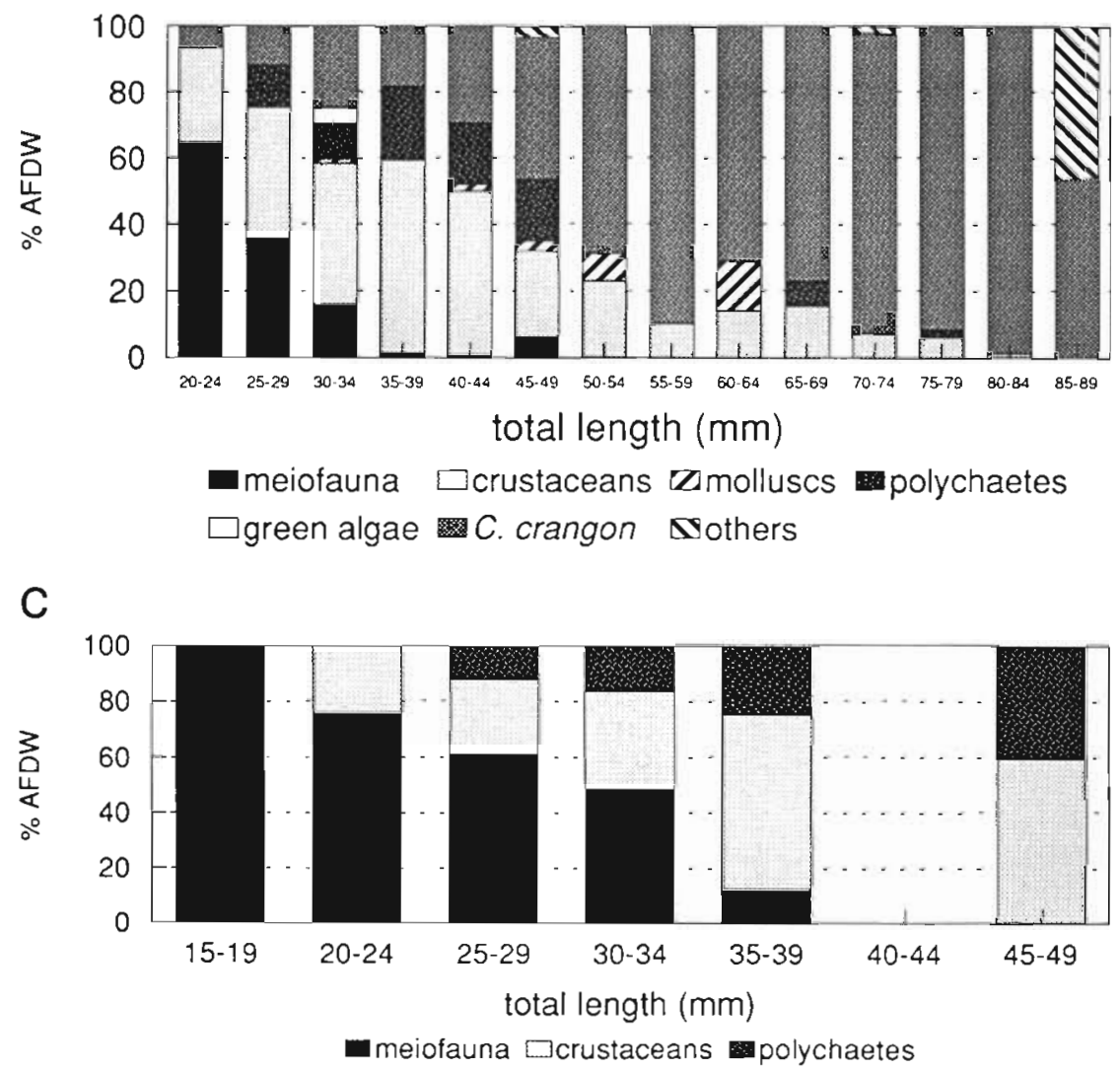

Fig 5. Diet composition by length class of (a) Crangon crangon ( $\mathrm{n}=553$ ); (b) Pomatoschistus minutus ( $\mathrm{n}=447$ ) and (c) $P$. microps ( $\mathrm{n}=184$ ) during the entire $24 \mathrm{~h}$ period

Shrimp fed mainly on crustaceans, mostly amphipods (25.9\%), polychaetes $(22.4 \%)$ and meiofauna $(22.6 \%)$. The smallest sizes preyed mainly on meiofauna (mostly foraminiferans\}, with decreasing quantities as shrimp size increased. Thereafter, macrofaunal taxa, such as polychaetes, crustaceans and molluscs became more important in the shrimps' diet. Cannibalism comprised only $3.4 \%$ of the overall gut contents and was observed only among larger length classes.

The relative proportion of each prey type in the stomach contents of Pomatoschistus minutus according to size is shown in Fig. 5b. Meiofauna (mainly harpacti- coids) was fed upon by the smallest individuals (up to $49 \mathrm{~mm}$ ), together with macrofauna, e.g. crustaceans (mostly mysids), polychaetes and molluscs. However, the most important prey item overall was Crangon crangon, preyed upon by all lengths of the sand goby. The shrimp comprised $28 \%$ of the diet of smaller gobies (20 to $54 \mathrm{~mm}$ ), while bigger gobies (>55 mm) fed only or predominantly $(77 \%)$ on the shrimp. The overall quantity of shrimp found in guts of all sizes of the sand goby was equivalent to $51 \%$.

Fig. 5c shows the stomach contents of Pomatoschistus microps by size class. Meiofauna (likewise mostly 
harpacticoids), comprising almost half of the total gut contents, decreased in importance with increase in goby size. Crustaceans (amphipods and mysids), comprising about $35 \%$ of the total, and polychaetes $(15.5 \%)$ were preyed upon increasingly with increase in predator size. Copepods and bivalves were also represented in the common goby's diet, however only in negligible quantities.

There was no discernible diel pattern in the diet composition of the 3 species. However, the sand goby fed consistently on the shrimp during the entire $24 \mathrm{~h}$ period, with quantities maintained at ca $50 \%$ of the total gut contents for each individual haul.

\section{Food niche overlaps}

Table 2 shows the food niche overlaps $\left(C_{x y}\right)$, computed by haul and averaged for the 24 h period. In general, the overlaps were rather low (around 0.1 to 0.2 ), except in a few hauls. The overlaps by haul were quite variable, and did not show a clear pattern. The mean values did not also differ considerably from one another. Table 3 shows, on the other hand, the niche overlaps computed by length class. The overlaps between the shrimp and the gobies were likewise within the same magnitude as above. However, those between the gobies were higher, especially among the smallest length classes, decreasing gradually with size. Since Pomatoschistus microps occurred only in sizes

Table 2. Crangon crangon, Pomatoschistus minutus and $P$. microps. Niche overlaps $\left(C_{x y}\right)$ between shrimp and gobies in a 24 h sampling period, northern Wadden Sea, July 1992

\begin{tabular}{|cccc|}
\hline Haul no. & $\begin{array}{c}\text { C. crangon/ } \\
\text { P. microps }\end{array}$ & $\begin{array}{c}\text { C. crangon/ } \\
\text { P. minutus }\end{array}$ & $\begin{array}{c}\text { P.microps } \\
\text { P. minutus }\end{array}$ \\
\hline 1 & 0.21 & 0.04 & 0.40 \\
2 & 0.15 & 0.11 & 0.09 \\
3 & 0.08 & 0.13 & 0.10 \\
4 & 0.01 & 0.24 & 0.08 \\
5 & 0.10 & 0.10 & 0.08 \\
6 & 0.13 & 0.03 & 0.10 \\
7 & 0.03 & 0.09 & 0.07 \\
8 & 0.05 & 0.12 & 0.05 \\
9 & 0.01 & 0.10 & 0.07 \\
10 & 0.07 & 0.06 & 0.25 \\
11 & 0.17 & 0.56 & 0.22 \\
12 & 0.17 & 0.47 & 0.31 \\
13 & 0.05 & 0.06 & 0.12 \\
14 & 0.34 & 0.09 & 0.07 \\
15 & 0.20 & 0.03 & 0.16 \\
16 & 0.25 & 0.01 & 0.09 \\
17 & 0.16 & 0.15 & 0.25 \\
Mean & 0.13 & 0.14 & 0.15 \\
SD & 0.09 & 0.15 & 0.10 \\
\hline
\end{tabular}

Table 3. Crangon crangon, Pomatoschistus minutus and $P$. microps. Niche overlaps $\left(C_{x y}\right)$ between shrimp and gobies by length class in a $24 \mathrm{~h}$ sampling period, northern Wadden Sea, July 1992

\begin{tabular}{cccc|}
\hline $\begin{array}{c}\text { Length class } \\
(\mathrm{mm})\end{array}$ & $\begin{array}{c}\text { C. crangon/ } \\
\text { P. microps }\end{array}$ & $\begin{array}{c}\text { C. crangon/ } \\
\text { P. minutus }\end{array}$ & $\begin{array}{c}\text { P.microps/ } \\
\text { P. minutus }\end{array}$ \\
\hline $15-19$ & 0.17 & - & - \\
$20-24$ & 0.25 & 0.15 & 0.67 \\
$25-29$ & 0.22 & 0.29 & 0.57 \\
$30-34$ & 0.19 & 0.18 & 0.35 \\
$35-39$ & 0.02 & 0.16 & 0.29 \\
$40-44$ & - & 0.16 & - \\
$45-49$ & 0.17 & 0.21 & 0.17 \\
$50-54$ & & 0.11 & \\
$55-59$ & & 0.23 & \\
$60-64$ & & 0.00 & \\
$65-69$ & & 0.01 & \\
& & &
\end{tabular}

smaller than $49 \mathrm{~mm}$, no niche overlaps for this species and the other 2 can be computed for larger sizes.

\section{Daily rations}

Table 4 shows the estimates of gastric evacuation rates and corresponding daily rations for Pomatoschistus microps, P. minutus and Crangon crangon based on the linear model. Computed daily rations based on the exponential model are presented later (see Table 6) for purposes of comparison with the literature. The daily ration estimates for $P$. microps and $P$. minutus were equivalent to $27.3 \%$ and $13 \%$ body weight, respectively. Estimates for $P$. minutus for all length classes were made, whereas data for $P$. microps and $C$. crangon were too patchy to allow separate calculations. In $P$. minutus, daily rations did not show any distinct pat-

Table 4. Crangon crangon, Pomatoschistus minutus and $P$. microps. Evacuation rates and daily rations at $18.5^{\circ} \mathrm{C}$ in the northern Wadden Sea, July 1.992. bw: body weight

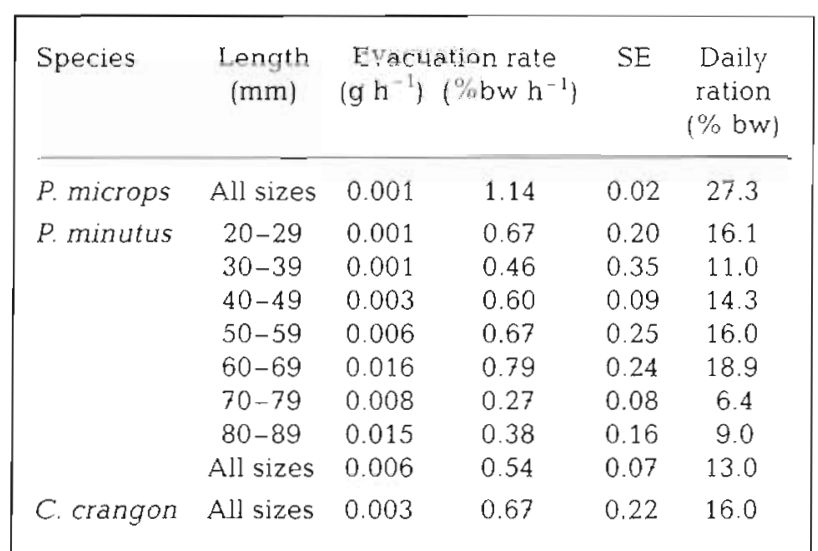


tern with increasing size. Average shrimp daily consumption was equivalent to $16 \%$ body weight.

\section{Predation impact}

Fig. 6a shows the pattern of predation of Pomatoschistus minutus on Crangon crangon according to size, summarized for all guts examined. As $P$. minutus increased in size, the size of $C$. crangon ( $\mathrm{TL}$ in $\mathrm{mm}$ ) preyed upon also increased. The relationship of sand goby size to the size of shrimp preyed upon can be described by the following linear regression equation: shrimp length $(\mathrm{mm})=-8.658+0.425$ sand goby length $(\mathrm{mm})\left(\mathrm{R}^{2}=0.539, \mathrm{n}=254\right)$. The quantity of $C$. crangon as a proportion of total prey (in \% AFDW) also increased with increase of goby size (Fig. 6b).

Size-specific predation impact on shrimp was examined by comparing estimates of the amount (weight) of shrimp preyed upon by size class with size-specific biomass estimates of shrimp available to gobies in the sampled area (Table 5). Biomass of available shrimp based on our own catch data was corrected for gear selection according to Berghahn (1984). The overall daily shrimp ration of Pomatoschistus minutus was computed by multiplying the daily ration estimate $(13 \%)$ with the actual proportion of shrimp $>10 \mathrm{~mm}$ TL $(49.3 \%)$ in sand goby gut contents. Together with the average sand goby biomass of $66.7 \mathrm{mg}$ wet wt $\mathrm{m}^{-2}$, the total daily shrimp ration of sand gobies was equivalent to $4.27 \mathrm{mg}$ wet wt $\mathrm{m}^{-2}$. Compared with the total available shrimp biomass of $1514.03 \mathrm{mg}$ wet $\mathrm{wt} \mathrm{m}^{-2}$, the overall daily predation impact on the shrimp popula-
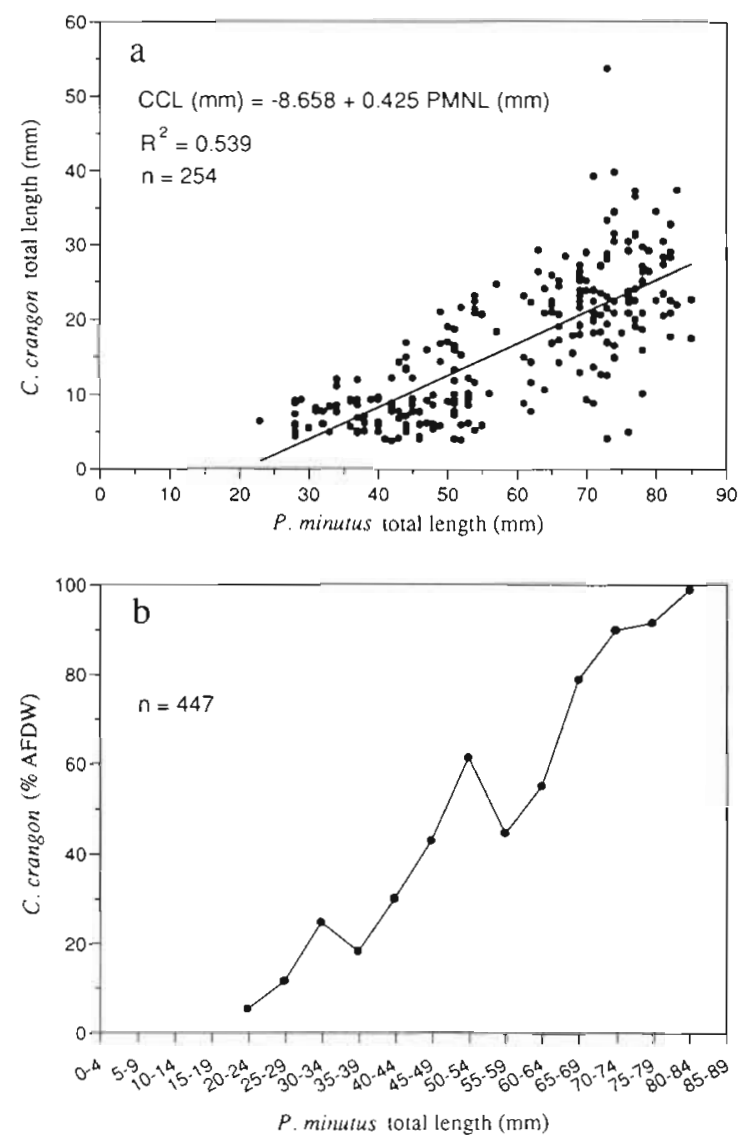

Fig. 6. Pomatoschistus minutus predation on brown shrimp Crangon crangon (CC). (a) Relationship of sand goby lengths (PMNL) (mm) to CC lengths (CCL) and (b) quantities of brown shrimp in percent AFDW of total sand goby gut contents

Table 5. Predation impact of Pomatoschistus minutus on Crangon crangon in a 24 h period, northern Wadden Sea, July 1992

\begin{tabular}{|c|c|c|c|c|c|}
\hline \multirow{2}{*}{$\begin{array}{l}\text { Shrimp } \\
\text { length } \\
\text { class (mm) }\end{array}$} & \multicolumn{2}{|c|}{ C. crangon preyed upon by $P$. minutus } & \multicolumn{3}{|c|}{ C. crangon occurrence in the area sampled (corrected) } \\
\hline & $\begin{array}{l}\text { Length- } \\
\text { frequency dist. } \\
(\%)\end{array}$ & $\begin{array}{c}\text { Daily shrimp ration } \\
\text { of sand goby } \\
\left.\text { (mg wet wt } \mathrm{m}^{-2}\right)\end{array}$ & $\begin{array}{l}\text { Length- } \\
\text { frequency dist. } \\
(\%)\end{array}$ & $\begin{array}{c}\text { Available shrimp } \\
\text { biomass } \\
\text { (mg wet wt } \mathrm{m}^{-2} \text { ) }\end{array}$ & $\begin{array}{c}\text { Daily sand goby } \\
\text { predation impact } \\
\text { on shrimp }(\%)\end{array}$ \\
\hline $1-4$ & 5.62 & 0.0004 & 0 & 0 & - \\
\hline $5-9$ & 32.13 & 0.05 & 0 & 0 & - \\
\hline $10-14$ & 11.62 & 0.09 & 4.55 & 3.27 & 2.75 \\
\hline $15-19$ & 12.05 & 0.29 & 16.98 & 37.30 & 0.78 \\
\hline $20-24$ & 20.08 & 1.12 & 27.83 & 140.80 & 0.80 \\
\hline $25-29$ & 12.45 & 1.35 & 18.30 & 180.28 & 0.75 \\
\hline $30-34$ & 4.02 & 0.76 & 10.25 & 175.91 & 0.43 \\
\hline $35-39$ & 2.01 & 0.61 & 10.46 & 288.52 & 0.21 \\
\hline $40-44$ & 0 & 0 & 6.54 & 273.69 & 0 \\
\hline $45-49$ & 0 & 0 & 2.42 & 146.19 & 0 \\
\hline $50-54$ & 0 & 0 & 1.54 & 130.22 & 0 \\
\hline $55-59$ & 0 & 0 & 0.92 & 105.35 & 0 \\
\hline $60-64$ & 0 & 0 & 0.15 & 22.74 & 0 \\
\hline $65-69$ & 0 & 0 & 0.05 & 9.76 & 0 \\
\hline Overall & & 4.27 & & 1514.03 & 0.28 \\
\hline
\end{tabular}


tion was estimated to be $0.28 \%$. When computed according to length, predation rate decreased, more or less, with size and ranged from 2.75 to $0.21 \%$ for shrimp between $10-14$ and 35-39 mm TL.

\section{DISCUSSION}

\section{Patterns in activity, feeding and niche overlaps}

All 3 species showed increasing densities towards dawn, with peaks shortly before or after dawn (Fig. 3a to $\mathrm{c}$. The common goby Pomatoschistus microps was more active during the day, with peaks in activity occurring mainly at dawn to sunrise, and to a lesser extent in the afternoon. Meyer-Antholz (1987) showed that there are 2 peaks in the activity of $P$. microps, one at dawn and one at dusk. He concluded that this pattern is endogenous, with the main activity phase between 05:00 and 18:00 h. The same day-active pattern in the common goby was also found by Magnhagen \& Wiederholm (1982). The pattern seen in $P$. minutus was more irregular, but the main peak was at dawn, between low and high tide. Gibson \& Hesthagen (1981) found no endogenous rhythm in $P$. minutus caught from a nontidal area, while the same species from a tidal area showed an endogenous rhythm, most likely influenced by tides. Although Wiederholm (1987) reported a higher activity level during daytime for both goby species, inversions in the activity peak of $P$. minutus have been documented, i.e. diurnal during winter and, as in our results here, nocturnal during summer (Westin \& Aneer 1987).

Both goby species showed similar feeding patterns with highest feeding during dawn and dusk (Fig. 4b, c). In both species, little feeding occurred during darkness. These results are consistent with those of previous studies conducted in other regions (Hesthagen 1971, Meyer 1982, Meyer-Antholz 1987, Antholz et al. 1991). Diurnal feeding and activity may be typical of gobies in general, as this has been observed in other species as well: Gobius niger (Hesthagen 1976, Nash 1982), Gobiusculus flavescens (Blegvad 1917), Caffrogobius caffer (Butler 1982), Deltentosteus quadrimaculatus (Villiers 1982) and Pomatoschistus pictus (Hesthagen 1980). Gibson (1969) observed the persistence of this pattern with and without the influence of tides. In nontidal areas, the trigger appears to be light (Hesthagen 1976, 1977, 1980, Manzer 1976, Meyer-Antholz 1987). For daylight feeders, it would be more advantageous to forage not during full daylight, but during the twilight hours (dusk and/or dawn), because they achieve cover from predation and, at the same time, take advantage of the vulnerability of the prey (Hesthagen 1973, 1976). Gobies and shrimp prey on ben- thic and planktonic organisms which in turn may exhibit other patterns of diel behavior and are, in comparison, not mobile enough to escape successfully from their predators.

Daytime feeding suggests that both sand and common gobies are visual feeders, with their feeding associated with light-dark and tidal cycles. Both feeding peaks of Pomatoschistus minutus were observed during and shortly after slack high tide, decreasing with the outgoing tide (Fig. 4b). Healey (1971) observed peak feeding in $P$. minutus at the Ythan Estuary in Scotland, UK, to be at high tide.

While both gobies were generally active during the day, shrimp density and feeding were highest during darkness, with peaks at dawn and dusk. Highest density and feeding were observed at dawn, shortly after slack low tide. Dahm (1975) noted that the highest shrimp catches in the fishery are taken during slack in tides, when currents are at their lowest velocities. Such conditions, which facilitate the search for food, are exploited by the shrimp, which in turn are caught more easily. Pihl \& Rosenberg (1984) observed similarly that the main feeding of Crangon crangon occurred during darkness, with peaks around dawn and dusk. In summer, however, a midday peak was also observed. Midday feeding, although not as pronounced, was also observed in the present study.

Estimates of niche overlap among the 3 species were low (Table 2). Similarly low overlap was observed by Pihl (1985) for July. While the data presented here represent only a single $24 \mathrm{~h}$ period, some size-related structure to these relationships among the 3 species can be recognized.

For the 3 species in general, prey size increased with predator size, their intake of meiofaunal taxa being gradually replaced by macrofaunal organisms. The feeding overlaps between Pomatoschistus microps and $P$. minutus of $<40 \mathrm{~mm}$ TL were relatively high, the pattern being most pronounced among the smaller sizes within this range (Table 3). With increase in size, the values decreased, reflecting diversification in their diets (Fig. 5b, c). Hamerlynck et al. (1986) reported similarly strong overlaps between the likewise sympatric gobies P. minutus and P. lozanoi from the Belgian coast. They conclude, though, that such values do not necessarily indicate competition because, as in this case, the 2 gobies exhibited vertical spatial segregation, temporal segregation in spawning and absence of niche shifts when one was temporarily absent. Most of the common gobies recorded during the present study were within the size range 15 to $35 \mathrm{~mm}$, which corresponds closely to the youngest cohort of $P$. minutus (Fig. 2b, c), with which higher overlap was shown. The absence of large $P$. microps probably reflects differences in preferred habitats of larger sand and common 
gobies. High niche overlaps often, if not always, indicate high availability of food and that competition first occurs when food resources become limiting (Schoener 1974, Werner 1986). In such shallow soft-bottom habitats, partitioning of abundant resources prevents epibenthic predators like gobies from outcompeting one another (Evans 1983). The lack of data on food availability in the present study does not permit inferring the possibility of food limitation. The results, however, suggest that both sand and common gobies exhibit intraspecific niche segregation by means of diet diversification (Fig. 5b, c) as they grow.

Intraspecific differences in diet is also shown for brown shrimp (Fig. 5a), but niche overlap with the 2 gobies remained low for all sizes of shrimp (Table 3). Shrimp cannibalism was relatively rare, but in some cases when it was observed, the niche overlaps between Crangon crangon and Pomatoschistus minutus were also higher (e.g. 45-49 mm, 55-59 mm; Table 3)

\section{Daily rations}

Considering that the nonfeeding phases during the $24 \mathrm{~h}$ period were not that distinct in our data, we estimated the evacuation rates within a short segment of the emptying phase using a linear model.

The estimated daily ration for Pomatoschistus microps (27.3\%) based on the linear model is comparable to the estimates of Thiel (1990) for the same species from the south Baltic Sea. Applying the Winberg method for data taken between April and October each year over a span of $2 \mathrm{yr}$, with temperatures ranging from 4.8 to $21.4^{\circ} \mathrm{C}$, he estimated the average daily ration of $P$. microps to be $34.3 \%$ for age group 0 and $27.7 \%$ for age group 1 . Andersen (1983) reported the daily ration of $P$. microps taken also from the Baltic to be $8.6 \%$ body weight (bw) at $17^{\circ} \mathrm{C}$. Meyer-Antholz (1987), who sampled in the Schlei (Baltic Sea), reported a range of 4.18 to $6.5 \%$ for different temperatures $\left(14\right.$ to $\left.17.5^{\circ} \mathrm{C}\right)$, gut fullness and age of fish.

For comparison, we also applied the exponential evacuation model developed by Andersen (1984) for Pomatoschistus microps, which takes length of fish and temperature into consideration. Using the average temperature $\left(18.5^{\circ} \mathrm{C}\right)$ during our sampling and the average fish size in our samples $(27 \mathrm{~mm})$, we derived much higher estimates of evacuation rate $\left(0.43 \mathrm{~h}^{-1}\right)$ and daily ration ( $47.7 \%$ bw). Similarly applying Andersen's (1984) equation to the data of Cattrijsse (1986) on P. Iozanoi with $12^{\circ} \mathrm{C}$ as average temperature, we derived evacuation rates almost 2 times higher $\left(0.3 \mathrm{~h}^{-1}\right.$ for $25 \mathrm{~mm}$ TL and $0.23 \mathrm{~h}^{-1}$ for $35 \mathrm{~mm}$ TL) compared to his own estimates $\left(0.16\right.$ and $0.13 \mathrm{~h}^{-1}$, respectively) based on experimental work. Perhaps the reason for these higher estimates is the fact that Andersen (1984) only used Nereis diversicolor as feed during his lab experiments. Jones (1974) reported that in haddock and whiting, Nereis sp. and Nepthys sp. (polychaetes) are eliminated faster $\left(0.31 \mathrm{~g} \mathrm{~h}^{-1}\right)$ than crustaceans $\left(0.19 \mathrm{~g} \mathrm{~h}^{-1}\right)$, in this case, Crangon sp. Applying Andersen's (1984) model to our present data may have resulted in overestimates since, based on our field data, $P$. microps preferred crustaceans (gammarids, mysids, cumaceans) to polychaetes as food.

Our daily ration estimate for Pomatoschistus minutus of $13 \%$ bw at $18.5^{\circ} \mathrm{C}$ falls within reported values. Healey (1971) estimated an annual average daily ration for $P$. minutus of $3.13 \%$ bw, with values ranging from $0.65 \%$ in December to $14.13 \%$ bw in August. In Sweden (Kattegat), Evans (1984) reported the range of daily ration for $P$. minutus to be 5 to $12 \%$ bw at 5 and $15^{\circ} \mathrm{C}$. In general, average stomach contents $(S)$ of both gobies in our samples were much higher than those in the literature (Table 6).

Pihl \& Rosenberg (1984) estimated the evacuation rate and daily food consumption of Crangon crangon through serial slaughter in the field. At 13.5 to $14^{\circ} \mathrm{C}$, they derived an evacuation rate of $0.58 \% b^{-1} \mathrm{~h}^{-1}$ and a daily consumption of $12.1 \%$ bw. They showed that evacuation was linear and under these conditions, food left the stomach within $2 \mathrm{~h}$. Evans (1984) reported a daily ration of 3 to $7 \%$ bw for 5 and $15^{\circ} \mathrm{C}$. Our higher estimate for $C$. crangon probably takes into account the higher temperature regime during our sampling.

To examine the variation in consumption with size, daily rations were also computed on a length class basis for Pomatoschistus minutus. Evacuation rates by length class varied rather considerably. This is probably due to the lack of appropriately sized individuals during some hauls and the irregular course of emptying in some length classes. However, if daily rations are averaged for size classes with similar gut contents, i.e. those smaller and larger than $55 \mathrm{~mm} \mathrm{TL}$, which respectively show a shift in selection from mixed meio-/macrofauna to pure macrofauna (Fig. 5c), a slight decrease ( 14.4 to $11.4 \%$ ) in values is apparent.

Comparison with values reported in the literature should be done with care, since published data on gastric evacuation experiments for the 3 species cover only a limited range of food types, temperatures and predator size classes (Table 6).

Special complications are caused by different treatments of the experimental meal size. The experimental meal size usually has a significant influence on the evacuation rates. If linear evacuation is assumed, the linear rate tends to increase with meal size; if exponential evacuation is assumed, the instantaneous coefficient is negatively correlated with meal size 


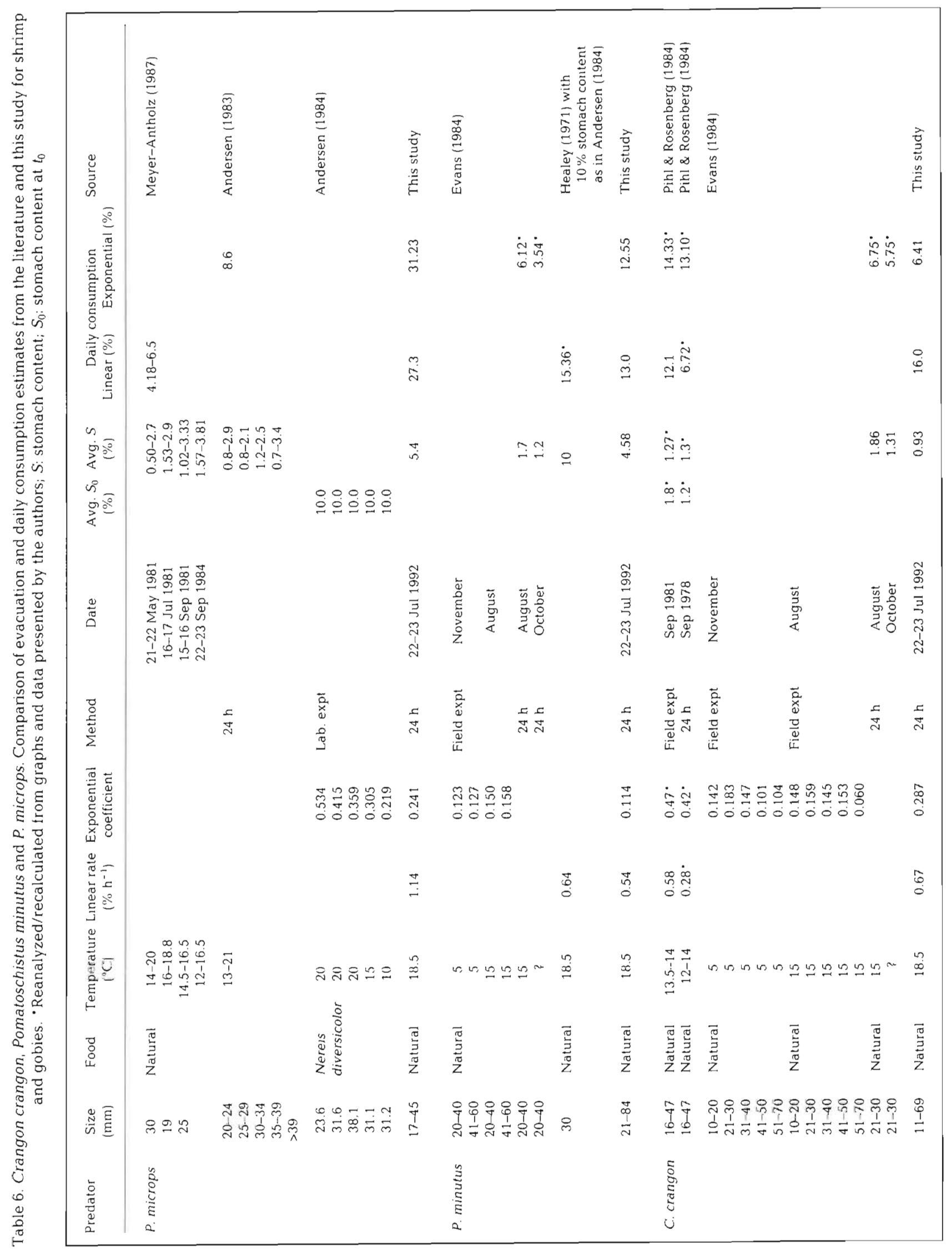


(Temming \& Andersen 1992). If meal size is then used as a variable in linear or exponential models (e.g. Healey 1971, Meyer-Antholz 1987), the real meal size of the fish in the field has to be guessed in order to apply the model. It is, however, not even clear how to define a meal size in the field, e.g. if the fish feed more or less continuously. Models should preferably be reparameterized without the variable meal size (Temming \& Andersen 1992). In some investigations, the meal size is kept in constant proportion of the body weight throughout the predator size range (Andersen 1984; Table 6). This is likely to be the reason why the estimated instantaneous coefficients of the exponential evacuation model decrease with increasing predator size. This is rather an effect of the increasing absolute meal size than of increasing predator size.

In Evans (1984; Table 6), the instantaneous coefficients of the exponential evacuation model decrease, in many cases, with temperature and in some cases, also with predator size. Presumably this again reflects the potential effect of variation in meal size.

During this study, feeding appeared to extend more or less throughout the whole $24 \mathrm{~h}$ cycle with less pronounced evacuation phases. The estimates reported here are therefore preliminary and should serve as baseline information for the area concerned. Because of rather limited information on evacuation rates, estimating reliable consumption rates for the investigated species will require further validation with more extensive sets of experimental data covering a wider range of conditions.

\section{Predation impact}

The estimate of overall predation impact on brown shrimp by the sand goby $(0.28 \%)$ applies only to shrimps $>10 \mathrm{~mm}$ in size. Based on the length distribution of shrimps in stomach contents, the sand goby preferred smaller shrimps, mainly those between 5-9 mm and 20-24 $\mathrm{mm}$ (Table 5). Although the estimated predation impact for smaller shrimps are higher compared to those of larger shrimps, the estimates for smaller sizes ( $<25 \mathrm{~mm}$ ) may be unrealistic because these sizes could not be adequately sampled by the gear. This is not only due to gear selection (which we corrected for), but more importantly because smaller shrimps are more abundant in shallower areas, like the tidal flats, where they predominantly occur, until they adopt tidal migration at a size of about $25 \mathrm{~mm}$ (Janssen \& Kuipers 1980). A daily predation impact of $0.3 \%$ of available biomass is probably not that significant in terms of the entire shrimp population, in view of their high turnover rates. Kuipers \& Dapper (1981) reported an average shrimp $\mathrm{P} / \mathrm{B}$ ratio of $8.0 \mathrm{yr}^{-1}$ or about $2 \% \mathrm{~d}^{-1}$.
Shrimp recruitment occurs continuously over the year in brood waves, while the gobies recruit mainly in summer In the present study, the sand goby preyed mainly upon 2 shrimp size groups, namely (1) $<10 \mathrm{~mm}$ which, based on a series of monthly length-frequency distributions independently made in the vicinity of the sampling area (including shallow flats), represents early summer recruits, which settled sometime between June and July; and (2) 20-24 mm which on the other hand corresponds to winter eggs. In the Dutch Wadden Sea, Kuipers \& Dapper (1984) suggested that both Pomatoschistus microps and P. minutus could decimate the shrimp brood between June and December, that is, the bulk only of the summer recruits. In further contrast to their results, $P$. microps seems to be unimportant as a predator for Crangon crangon. The predation impact of $P$. minutus on the Crangon population is unlikely to control the recruitment of the summer brood, since part of the predation pertains to the winter brood and the remainder is low, when compared to production. The present results suggest though that the timing of the arrival of shrimp new recruits versus the sizes of gobies present which can actually prey on them is an important factor to consider in assessing predation impact.

In summary, the gobies Pomatoschistus microps and $P$. minutus and the brown shrimp Crangon crangon exhibit daily patterns in activity and feeding. However, these patterns, together with their functional significance, became more evident when size classes of the 3 species were examined and compared. Such patterns include the food niche overlap between small gobies, the spatial segregation between large sand and common gobies (apparent from size distributions) and food niche segregation between gobies as they grow (decreasing trend within size classes compared). The size distributions of shrimp in the stomachs of $P$. minutus led to the conclusion that more small shrimp are eaten than large shrimp and that these belong both to the winter and summer broods. For these shrimp and goby populations, it appears that predation plays a more meaningful role than competition in determining the nature and extent of their ecological interactions.

Acknowledgements. We thank S. Jansen, G. Hemken and J. Dresbach for collecting the samples, $\mathrm{S}$. Jansen for providing access to additional information and material and R. Thiel for commenting on the draft. We are grateful to $A$. Sepulveda for the help in the preparation of graphs and tables and to W. L. Campos for suggestions which helped to improve the content and style of the manuscript. This work is part of a doctoral study by the senior author at the Faculty of Biology, University of Hamburg, supported financially by the German Academic Exchange Service (DAAD). 


\section{LITERATURE CITED}

Andersen, N. G. (1983). Lehrkutlingen Pomatoschistus microps (Kr.) in Niva bugt. Ph.D. dissertation, University of Copenhagen

Andersen, N. G. (1984). Depletion rates of gastrointestinal content in common goby (Pomatoschistus microps) (Kr.). Effects of temperature and fish size. Dana $3: 31-42$

Antholz, B., Meyer-Antholz, W., Zander, C. D. (1991). Feeding activities of two euryhaline small-sized fish in a western Baltic brackish fjord. Helgoländer Meeresunters. 45: $287-300$

Bajkov, A. D. (1935). How to estimate the daily food consumption of fish under natural conditions. Trans. Am. Fish. Soc. 65: 288-289

Berghahn, R. (1984). Zeitliche und räumliche Koexistenz ausgewählter Fisch- und Krebsarten im Wattenmeer unter Berücksichtigung von Räuber-Beute-Beziehungen und Nahrungskonkurrenz. Ph.D. dissertation, Universität Hamburg

Blegvad, A. D. (1917). On the food of fish in the Danish waters within the skaw. Rep. Dan. Biol. Stn 24: 17-72

Butler, G. S. (1982). Daily feeding periodicity of the intertidal goby Caffrogobius caffer. S. Afr. J. Zool. 17(4): 182-189

Cattrijsse, A. (1986). Experimenteel en Veldonderzoek naar de 24 -uurkonsumptie en het Voedingsritme van Pomatoschistus spec. (Pisces, Gobiidae). M.Sc. thesis, Rijksuniversiteit Gent-Fakulteit der Wetenschappen

Dahm, E. (1975). Untersuchungen zum Nahrungserwerb von Crangon crangon Linne. Ber. Dtsch. wiss. Komm. Meeresf. Sonderdr. 24 (2-3): 105-133

Evans, S. (1983). Production, predation and food niche segregation in a marine shallow soft-bottom community. Mar. Ecol. Prog. Ser. 10: 147-157

Evans, S. (1984). Energy budgets and predation impact of dominant epebenthic carnivores on a shallow soft bottom community at the Swedish west coast. Estuar. coast. Shelf Sci. 18: $651-672$

Evans, S., Tallmark, B. (1979). A modified drop-net method for sampling mobile epifauna on marine shallow sandy bottoms. Holoarct. Ecol. 2: 58-64

Evans, S., Tallmark, B. (1984). Seasonal dynamics of small vagile predators on a marine shallow soft bottom. Holoarct. Ecol. 7: 138-148

Evans, S., Tallmark, B. (1985). Niche separation within the mobile predator guild on marine shallow soft bottoms. Mar. Ecol. Prog. Ser. 23: 279-286

Faubel, A. (1982). Determination of individual meiofauna dry weight values in relation to definite size classes. Cah. Biol. mar. 23: 339-345

Fonds, M. (1973). Sand gobies in the Dutch Wadden Sea (Pomatoschistus. Gobiidae, Pisces). Neth. J. Fish. Res. 6(4): $417-478$

Gayanilo, F., Soriano, M., Pauly, D. (1989). A draft guide to the compleat ELEFAN. ICLARM Software 2. International Center for Living Aquatic Resources Management, Manila

Gibson, R. N. (1969). The biology and behaviour of littoral fish. Oceanogr. mar. Biol. A. Rev. 20: 363-414

Gibson, R. N., Hesthagen, I. H. (1981). A comparison of the activity patterns of the sand goby Pomatoschistus minurus (Pallas) from areas of different tidal range. J. Fish. Biol. 18: $669-684$

Hamerlynck, O., Heip, C., Redant, F. (1986). Life history, food consumption and resource partitioning in two sympatric gobies Pomatoschistus minutus and $P$. lozanoi in the Belgian coastal waters. Comm. Meet. int. Coun. Explor. Sea C.M.-ICES 1986/L: 14 Sess. R
Healey, M. C. (1971). The distribution and abundance of sand gobies, Gobius minutus, in the Ythan estuary. J. Zool., Lond. 163: 177-229

Hesthagen, 1. H. (1971). The winter food of the gobies from one of the deeper channels of Belt Sea, with particular reference to the sand goby, Pomatoschistus minutus. Kieler Meeresforsch. 27(1): 28-35

Hesthagen, I. H. (1973). Diurnal and seasonal variations in the near-bottom fauna - the hyperbenthos - in one of the deeper channels of the Kieler Bucht (Western Baltic). Kieler Meeresforsch. 29(2): 116-140

Hesthagen, I. H. (1976). Locomotor activity of the black goby, Gobius niger L. (Pisces, Gobiidae), under artificial conditions, including a false dawn and dusk. Sarsia 62: 9-18

Hesthagen, I. H. (1977). Migrations, breeding and growth in Pomatoschistus minutus (Pallas) (Pisces, Gobiidae) in Oslofjorden, Norway. Sarsia 63: 17-26

Hesthagen, I. H. (1980). Locomotor activity in the painted goby, Pomatoschistus pictus (Malm) (Pisces) in relation to light intensity. Sarsia 65: 13-18

Hureau, J. C. (1969). Biologie comparée de quelques poissons antarctiques (Nototheneidae). Bull. Inst. Océanogr. Monaco 68: 1-131

Hurlbert, S. H. (1978). The measurement of niche overlap and some relatives. Ecology 59(1):67-77

Janssen, G. M., Kuipers, B. R. (1980). On tidal migration in the shrimp Crangon crangon. Neth. J Sea Res. 14(3/4) $339-348$

Jones, R. (1974). The rate of elimination of food from the stomachs of haddock Melanogrammus aeglefinus, cod Gadus morhua and whiting Merlangius merlangus. J. Cons. int. Explor. Mer 35(3): 225-243

Kühl, H. (1964). Protokolle zu den Nahrungsuntersuchungen an einigen Fischen der Elbmündung. Veröff. Inst. Küst. Binnenfisch. Hamburg No. 32/1964

Kühl, H. (1972). Hydrography and biology of the Elbe estuary. Oceanogr. mar. Biol. A. Rev. 10: 225-309

Kuipers, B. R. Dapper, R. (1981). Production of Crangon crangon in the tidal zone of the Dutch Wadden Sea. Neth. J. Sea Res. 15(1): 33-53

Kuipers, B. R., Dapper, R. (1984). Nursery function of Wadden Sea tidal flats for the brown shrimp Crangon crangon. Mar. Ecol. Prog. Ser. 17: 171-181

Magnhagen, C., Wiederholm, A. M. (1982). Food selectivity versus prey availability: a study using the marine fish Pomatoschistus microps. Oecologia 55: 311-315

Manzer, J. I. (1976). Distribution, food and feeding of the threespined stickleback, Gasterosteus aculeatus, in Great Central Lake, Vancouver Island, with comments on competition for food with juvenile sockeye salmon (Oncorhynchus nerka). Fish. Bull. U.S. 74(3): 647-668

Meyer, W. (1982). Untersuchungen über den Tageszeitenrhythmus und die Verdauungsraten der Strandgrundel (Pomatoschistus microps, Kroyer 1838) (Gobiidae, Pisces). M.Sc thesis, Universität Hamburg

Meyer-Antholz, W. (1987). Untersuchungen über Verdauungsraten, Freßrhythmen and lokomotorische Aktivitäten der Strandgrundel, Pomatoschistus microps (Krøyer 1838) (Gobiidae, Pisces), und ihre Anwendung zur Bestimmung der Tagesration. Ph.D. dissertation, Universität Hamburg

Miller, P. J. (1973). Gobiidae. Checklist of the fishes of the northeastern Atlantic and of the Mediterranean, Vol. 1 p. 483-515; Vol. 2, p. 320-321. UNESCO, Paris

Nash, R. D. M. (1982). The diel behavior of small demersal fish on soft sediments on the west coast of Scotland using a variety of techniques: with special reference to Leseurogobius frisii (Pisces, Gobiidae). Mar. Ecol. 3(2): 161-178 
Pihl, L. (1985). Food selection and consumption of mobile epibenthic fauna in shallow marine areas. Mar. Ecol. Prog. Ser. 22: 169-179

Pihl, L., Rosenberg, R. (1982). Production, abundance and biomass of mobile epibenthic marine fauna in shallow waters, western Sweden. J. exp. mar. Biol. Ecol. 57: 273-301

Pihl, L., Rosenberg, R. (1984). Food selection and consumption of the shrimp Crangon crangon in some shallow marine areas in western Sweden. Mar. Ecol. Prog. Ser. 15: $159-168$

Redant, F. (1980). Population dynamics of brown shrimp (Crangon crangon) in the Belgian coastal waters. 2. Predation mortality. Comm. Meet. int. Coun. Explor. Sea C. M. ICES 1980/K: 33

Rolle, B. (1982). Experimentelle Untersuchungen zur intraspezifischen Konkurrenz bei der Nordseegarnele Crangon crangon (L. 1758) insbesondere im Hinblick auf den Kannibalismus. M.Sc. thesis, Universität Hamburg

Sander, P. (1987). Ökologische Untersuchungen des Makrobenthos im Eulitoral des Helmsander Watts. M.Sc. thesis, Universität Hamburg

Schoener, T W. (1974). Resource partitioning in ecological communities. Science 185: 25-39

Sokal, R. R., Rohlf, F. J. (1981). Biometry, 2nd edn. W. H. Freeman and Co., San Francisco

Temming, A., Andersen, N. (1992). Modelling gastric evacuation in cod. Comm. Meet. int. Coun. Explor. Sea C.M.ICES 1992/G: 61

Thiel, R. (1990). Untersuchungen zur Ökologie der Jung- und Kleinfischgemeinschaften in einem Boddengewässer der südlichen Ostsee. Ph.D. dissertation, Universität Rostock

Thorman, S. (1982). Niche dynamics and resource partition-

This article was submitted to the editor ing in a fish guild inhabiting a shallow estuary on the Swedish west coast. Oikos 39: 32-39

Thorman, S. Wiederholm, A. M. (1983). Seasonal occurrence and food resource use of an assemblage of nearshore fish species in the Bothnian Sea, Sweden. Mar. Ecol. Prog. Ser 10: $223-229$

Thorman, S., Wiederholm, A. M. (1984). Species composition and dietary relationships in a brackish shallow water fish assemblage in the Bothnian Sea, Sweden. Estuar. coast. Shelf Sci. 19: 359-371

Thorman, S., Wiederholm, A. M. (1986). Food, habitat and time niches in a coastal fish species assemblage in a brackish water bay in the Bothnian Sea, Sweden. J. exp. mar. Biol. Ecol. 95: 67-86

Tiews, K. (1970). Synopsis of biological data on the common shrimp Crangon crangon (Linnaeus, 1758). FAO Fish. Rep. 57(4): 1167-1221

Tiews, K. (1978). The predator-prey relationship between fish populations and the stock of brown shrimp (Crangon crangon L.) in German coastal waters. Rapp. P.-v. Réun. Cons. int. Explor. Mer 172: 250-258

Villiers, L. (1982). The feeding of juvenile goby Deltentosteus quadrimaculatus (Pisces, Gobiidae). Sarsia 67: 157-162

Werner, E. E. (1986). Species interactions in freshwater communities. In: Diamond, J., Case, T. J. (eds.) Community ecology. Harper and Row, New York, p. 344-357

Westin, L., Aneer, G. (1987). Locomator activity patterns of nineteen fish and five crustacean species from the Baltic Sea. Environ. Biol. Fish. 20: 49-65

Wiederholm, A. M. (1987). Habitat selection and interactions between three marine fish species (Gobiidae). Oikos 48: $28-32$

Manuscript first received: July 4, 1994

Revised version accepted: September 23, 1994 